Www.jmscr.igmpublication.org

Impact Factor (SJIF): 6.379

Index Copernicus Value: 79.54

ISSN (e)-2347-176x ISSN (p) 2455-0450

crossrefDOI: https://dx.doi.org/10.18535/jmscr/v7i1.75

Journal Of Medical Science And Clinical Research

IGM Publication

An Official Publication of IGM Publication

\title{
Knowledge, Attitudes, and Practices of Primary Health Care Physicians in the Screening and Prevention of Elderly Falls at Alwazarat Health Center, Riyadh, KSA
}

\author{
Author \\ Dr Saad S. Alshahrani, MBBS \\ Prince SULTAN Medical Military City, Riyadh \\ Corresponding Author \\ Saad Shebnan Alshahrani \\ Riyadh, KSA \\ Phone: 966567999456, Email: saadshebnan@gmall.com
}

Department of Family Medicıne, Prince Sultan Medical Militiary City, Alwazarat Health Care Center,

\begin{abstract}
Background: Elderly, occupational retirees. ${ }^{(1)}$ In KSA, $51 \%$ of the elderly report a history of falls at leastonce in the past 12 months, and half of them have a history of recurrent falls, with larger ratesin certain chronic disease groups. ${ }^{(5)}$ With serious injuries there occur complications and higheconomic costs. The objective of the study is to evaluate the primary health care physicians' knowledge, attitudes, and practices regarding the screening and prevention of elderly falls.

Methods: A cross-sectional study conducted at the ALWAZART Center at PRINCE SULTAN MEDICAL MILITARY CITY in RIYADH City, KSA.A total of 86 questionnaires out of 96 distributed having 30 questions about physicians' knowledge, attitudes, and practices were completed and returned for a response rate of $90 \%$. Data were analyzed using SPSS. The p-value for significance was $<0.05$.

Results: The knowledge of physicians was divided into the categories of good, 27.9\%; intermediate, $39.5 \%$; low, 31.4\%; and very low, 1.2\%. Of the physicians, 35.5\% do not follow any guidelines regarding elderly fall screening and prevention, $15 \%$ always ask for the previous history of falls, $19.8 \%$ prescribe Vitamin D for fall prevention, $26.7 \%$ always advise exercise, and $53.5 \%$ have never been trained in the screening and prevention of falls among the elderly.

Conclusion: From the results of the study, we found different levels of knowledge among the physicians regardingthe screening and prevention of falls among the elderly, with the greatest proportion at the intermediate level ( $n=34:$ 39.5\%). Further studies and professional educational programs are required and local recommendations and an approved screening scale are needed.

Keyword: prevention, physicians, screening, elderly, knowledge, falls.
\end{abstract}

\section{Introduction}

Our nation's elderly population is increasing and is in need of more qualified health care screening and prevention. With their easy access to the community and comprehensive knowledge about most of the common diseases, primary health care physicians play an important role in providing care, promoting the health of the general 
population, and educating and screening people who are at risk of accidents such as falls. To date, the screening and prevention in primary health care of falls among elderly is marked by a lack of scientific studies evaluating the knowledge, attitudes, and practices of physiciansin Saudi Arabia.

\section{Background}

As there is no universally agreed definition of theelderly by age group,the World Health Organization createda general definition differing from one country to another depending on the age when the person becomes eligible for occupational retirement. ${ }^{(1)}$

According to the Cambridge Dictionary, a fall is when a person "suddenly go [es] down onto the ground or towards the ground without intending to or by accident."(2)

Reducing the risk of patient harm resulting from falls is one of six International Patient Safety Goals, in addition to Identifying patients correctly, improving communication, Improving the safety of high-alert medications, Assuring correct-site, correct-procedure, correct-patient surgery, and Decreasing the risk of health-care-related infection.

Internationally, among the elderly one out of every four had fallen once in the last year, ${ }^{(3)}$ with a prevalence of $28-35 \%$. $^{(4)}$ In Saudi Arabia, unfortunately, $51 \%$ of the elderly report a history of a fall in the past 12 months, half of them had a history of recurrent falls, and the number was greaterin chronic disease groups. ${ }^{(5)}$

Numerous international guidelines have been published discussing the screening and prevention of elderly falls, such as the USPSTF, NICE, and American Geriatrics Society guidelines, which include numerous details about the screening and prevention of elderly falls.

In the ALWAZARAT center the MORSE Fall Risk Assessment is used for all our geriatric patients. The tools can be used by staff nurses and involve a determination of the history of falls, secondary diagnosis, ambulatory aid, IV/heparin lock, gait/transferring, and mental state to yield a score used to classify elderly patientsas high, moderate, and low risk. The aim of this studyis to improve the implementation of elderly patient care in SAUDI ARABIA.

\section{Project Objectives}

To evaluate the primary health care physician's level of knowledge, attitudes, and practices regarding screening and prevention of falls in the elderly.

\section{Literature Review}

According to $\mathrm{WHO}$, there is no general agreement on the age at which a person becomes old, but the age at which a person becomes eligible for occupational retirement has become the most common definition. ${ }^{(1)}$

In 2010, an estimated 524 million people worldwide, representing $8 \%$ of the world's population, were aged $65 \mathrm{y}$ and above.

Internationally, millions of older adults suffer falls every year. One out of every four older people suffers a fall each year, ${ }^{(3)}$ with a prevalence of 28 $35 \%$ of thoseaged $65 \mathrm{y}$ and above suffering at least one fall each year, increasing to $42 \%$ among those $70 \mathrm{y}$ and older. ${ }^{(4)}$ Of these, $20 \%-30 \%$ of them will sufferserious injury. ${ }^{(6-7)}$ Moreover, falling once doubles the chances offalling again. ${ }^{(8)}$

A study by Pamela l.owens published in 2009 found that one of every ten ER visits among the elderly $>65 y$ was due to fall injuries, with $41 \%$ suffering fractures, $22.6 \%$ superficial injuries, and $21.4 \%$ open wounds as complications. Arm and hip fractures were the most common fall-related injuries. ${ }^{(9)}$

SAMIRA AL SENANY and AMER AL SAIF published a study carried out in Saudi Arabia in 2015 assessing the physical health status and quality of life among older Saudi adults. With a total of 55 male and female elderly subjects with ages ranging between 60 and 90 years, they found $51 \%$ of this group of the elderly had fallen once in their lives and $49 \%$ more than once in the past 12 months. The prevalence is greater in the case of 
chronic diseases such as DM (58.18\%) and HTN $(29.0 \%){ }^{(5)}$

The dramatic increase in the elderly population around the world and the long lives of individuals make caring for the elderly an important issue, especially in the prevention and screening of common problems of the elderly. One such problem is falls.

Effective falls prevention programs include:

- Screening for the risk of falls by asking all the elderly patients if they have fallen in the past 12 months, and the frequency and circumstances of falls. We should determine whether elderly patients have had difficulties in walking or balance. ${ }^{(11)}$

- Multifactorial falls risk assessment, used for patients who have a recurrent history of falls or abnormal gait and balance. ${ }^{(11)}$ Thisincludes a fall-focused history to collect information about the falls: when, where, prodromal symptoms like dizziness, loss of consciousness, frequency, medications, history of relevant risk factors such as comorbidity with agerelated diseases like OA or dementia, patient's daily activities, and assessment of theenvironment. ${ }^{(11-12)}$

- During examination we should performfull musculoskeletal, neurological, and cardiovascular examinations involving vital signs and postural vital signs to rule out postural hypotension, which is defined as a drop in systolic or diastolic blood pressure by 20 or $10 \mathrm{~mm} \mathrm{Hg}$ within three minutes of standing compared to that in a sitting or supine position. ${ }^{(13)}$ Also, we should perform a visual acuity test and hearing assessment using a whispered voice test: "Stand at arm's length behind the patient and mask hearing in one ear, then whisper a short word and numbers and ask the patient to repeat them, ${ }^{(14) "}$ lower limb examination, examination of the feet and footwear, neurological examination, and examination of musculoskeletal function by a series of tests; "get up and go is one of the best.",(12) The USPSTF recommends against "automatically" performing a multifactorial risk assessment for all older community-dwelling adults due to small benefit. ${ }^{(30)}$

- Diagnostic test: Can help in detecting the risk of falls: "hemoglobin, serum urea, creatinine, glucose and vitamin D."(12)

- Intervention assist: Instituting appropriate exercise programs, managing the risk factors, dealing with environmental factors, and ensuringa daily vitamin D supplement of $800 \mathrm{IU}^{(\mathbf{1 0})}$ for ages above $70 \mathrm{y}$ and 600 IU for ages 50-70y. ${ }^{(15)}$ Vitamin D is the only intervention that can decrease the rate in long-term care. ${ }^{(\mathbf{1 6})}$

\section{Research Design}

Descriptive cross-sectional study.

\section{Methods}

Using a cross-sectional design, we proposed to evaluate the knowledge, attitudes, and practices of primary health care physicians toward the screening and prevention of falls among the elderly. Started in February 2016 and ended in August 2017.

The study was conducted in the ALWAZARAT Health Care Center in RIYADH, KSA. It is one of the largest primary healthcare centers in KSA, under the Medical Service Department (MSD) of the Ministry of Defense. It is accredited by the Joint Commission on International Accreditation (JCIA).

The study population was primary health care physicians at the ALWAZARAT Health Care Center after theexclusion of pediatric, antenatal, and mental health physicians. The required sample size was calculated as 96 using the formula $S S=\left(Z^{2} *(p) *(1-p)\right) / c^{2}$, with the Correction for Finite Population formula: new SS $=S S /(1+(\mathrm{SS}-1) /$ population $)$, with confidence level $=95 \%$, confidence interval $=5$, and 
population $=128$. The sample size formula is available online

at: www.surveysystem.com/sscalc.htm ${ }^{(17)}$

The sampling technique was simple randomized sampling using the Randomizer web site, https://www.randomizer.org. ${ }^{(18)}$

The questionnaire was designed as a self-reported questionnaire with a Likertscale to assess the knowledge, attitudes, and practices of primary health care physicians. Validation was performed and reviewed by 4 consultants of family medicine and one biostatistician. Also, a test-retest and pretesting study were performedon 10 physicians representative of the study population to determine the clarity of the language, questionnaire structure, and difficulties that might arise when distributing and collecting the questionnaires.

The questionnaire is divided into 6parts:

- Demographic questions, Questions Nos. 1 to 5.

- Question No. 6 on thedefinition of elderly.

- Questions Nos. 7 to 18 evaluated the knowledge level.

- Questions Nos. 19 to 22 assessed attitudes.

- Questions Nos. 23 to 28 assessedpractice.

- Questions Nos. 29 and 30 on the MORSE Fall Screening Scale.

The questionnaires were distributed at the clinicsover a period of 3 months and collected at the end of the study by the researcher. Data were analyzed using SPSS version 20.

Ethics approval was obtained from the Ethics Committee of theFamily Medicine Department and the Research Ethics Committee of the Research Center of Prince Sultan Military Medical Center as Project No. 811. All of the participants provided consent agreeing to participate in the study.

\section{Results}

Ninety-six questionnaires were distributed, of which 86 were completed and returned, resulting in a response rate of $89.5 \%$ The analysis was based on these replies.
Table 1- Demographic data of the physicians

\begin{tabular}{lcc}
\hline Demographic characteristics & $N$ & $\%$ \\
\hline Gender & 58 & 67.4 \\
Male & 28 & 32.6 \\
Female & & \\
Age & 42 & 49.4 \\
20-29 years & 34 & 40 \\
30-39 years & 4 & 4.7 \\
40-49 years & 5 & 5.9 \\
50 and above & & \\
Job level & 3 & 3.5 \\
Consultant & 5 & 5.8 \\
Senior Registrar & 12 & 14 \\
Registrar & 66 & 76.7 \\
Resident & & \\
Qualification & 61 & 70.9 \\
MBBS & 12 & 14 \\
Saudi Board & 4 & 4.7 \\
MRCGB & 1 & 1.2 \\
Arab Board & 8 & 9.3 \\
Other & & \\
Years of experience & 23 & 27.1 \\
Less than 2 years & 35 & 41.2 \\
2-5 years & 14 & 16.5 \\
6-10 years & 13 & 15.3 \\
More than 10 years & & \\
$\quad$ & & \\
\hline & &
\end{tabular}

The general characteristics of participants are presented in Table1.The majority of participants were male, with a male-to-female ratio of 2.07:1. With a mean age $( \pm S D)$ of 31.99 (8.274) years and range of 24-65 years, the majority of physicians' ages were between 20 and 29 years ( $n=42$ : $49.4 \%)$.

The majority of physicians (76.7\%)were residents ( $n=66$ ). And majority of physicians with experience $2-5$ years $41.2 \%$.

Turning to the results for the definition of "elderly," $55.8 \% \quad n=48$ ) of the physicians considered a person with an age above $60 y$ elderly, while only $2.3 \%(n=2)$ considered a person above 50y elderly, and 30.2\% ( $n=26)$ a person above $70 \mathrm{y}$.

Knowledge assessment: Turning to the answers tothe knowledge assessment questions shown in Table 2 , the mean $( \pm S D)$ score was 60.65 (20.408), and scores ranged from 20.83 to 100.Only27.9\% $(n=24)$ physicians answered $75 \%$ or more of the questions correctly, $39.5 \%(n=34)$ correctly answered $50-75 \%, 31.4 \% \quad(n=27)$ 
answered 25-50\% correctly, and only one physician (1.2\%) scored below 25\%. The questions that were correctly answered the most by primary health care physicians were those concerning visual, hearing, gait, and cognitive assessment as a part of multifactorial risk assessment of falls in the elderly ( $n=56,75.6 \%)$, hemoglobin, urea, creatinine, glucose, and vitamin $\mathrm{D}$ as a part of investigations ( $n=61,70.9 \%)$, and the need to review the patient's medications as a part of fall screening and assessment ( $n=54$, $62.8 \%)$.

Table 2 - Evaluation of the knowledge of primary health care physicians in the ALWAZARAT Health Care Center

\begin{tabular}{lcc}
\hline Knowledge level & $N$ & $\%$ \\
\hline Good & 24 & 27.9 \\
Intermediate & 34 & 39.5 \\
Low & 27 & 31.4 \\
Very low & 1 & 1.2 \\
\hline
\end{tabular}

On the other hand, the questions that were correctly answered the least were the three concerning Vitamin D and the recommended dose as a part of a fall prevention program, as shown in Table 3 presenting the numbers and percentages of correct answers for the questions used to evaluate the knowledge of primary health care physicians.

Table 3 Numbers and percentages of correct answers to questions used to evaluate the knowledge of primary health care physicians

\begin{tabular}{llll}
\hline Question & $N$ & $\%$ \\
\hline $\begin{array}{l}\text { To screen the risk of falls among elderly persons } \\
\text { we have to ask all elderly patients if they have }\end{array}$ & 47 & 54.7 \\
fallen in the last 12 months. & & \\
$\begin{array}{l}\text { Multifactorial risk assessment is used for the } \\
\text { elderly with recurrentfalls or gait and balance }\end{array}$ & 36 & 41.9 \\
abnormality. & & \\
$\begin{array}{l}\text { DM, HTN, and other comorbidities will increase } \\
\text { the risk of fall among elderly patients. }\end{array}$ & 54.7 \\
$\begin{array}{l}\text { Visual, hearing, gait, and cognitive assessments } \\
\text { should be part of themultifactorial risk }\end{array}$ & 65 & 75.6 \\
assessment of falls in the elderly. & & \\
$\begin{array}{l}\text { Orthostatic hypotension is one of the important } \\
\text { risk factors, defined asa decrease in systolic }\end{array}$ & & \\
blood pressure of 20 mmHg or decrease in & 48 & 55.8 \\
diastolic blood pressure of 10 mmHg within 3 & &
\end{tabular}

minutes of standing in comparison to a sitting or supine position.

Falling once doubles the chance among the elderly offalling again.

$33 \quad 38.4$

Hemoglobin, urea, creatinine, glucose, and vitamin D can help in detecting the risk of falls in elderly patients.

We have to review elderly medications as a part of fall risk assessment.

The recommended intervention for prevention of falls among elderly are: An exercise program, managing risk factors, dealing with environmental factors, and vitamin D supplements.

The best intervention to decrease the rate of falls in thelong term is vitamin D supplements.

The recommended dose of vitamin D supplements for fall prevention in the elderly $>70$ is $800 \mathrm{IU} /$ day.

The recommended dose of vitamin D supplement for falls preventionin those aged $50-70$ is $600 \mathrm{IU} /$ day.

$61 \quad 70.9$

$54 \quad 62.8$

$41 \quad 47.7$

$41 \quad 16.3$

$9 \quad 10.6$

High knowledge scores, defined as scores $>75 \%$, were distributed by physician's age as follows: 30-39y had $70 \%$ versus $30 \%$ forall other age groups $(P \leq 0.01)$. Moreover,70.8\% ( $P=.57)$ of the high-knowledge respondents weremale, $70.8 \%$ ( $P=.02)$ were resident physicians versus the other groups, $41.7 \%$ ( $P=0.086)$ were physicians with 2 to 5 years of experience, and $70.8 \%(P=.47)$ were MBBS-qualified physicians.

Attitude assessment: Seventy physicians (81.4\%) agreed that falls among the elderly in Saudi Arabia areprevalent, and $32.8 \%$ of them indicated strong agreement. Moreover, 91.7\%( $n=78)$ agreed that falls among the elderly area major problem, with $58.9 \%$ of them strongly agreeing. Furthermore, $96.5 \%$ of them $(n=83)$ agreed that the primary health care physician playsan important role in the screening and prevention of falls among older people, with $65 \%$ of them strongly agreeing; and $66.2 \%(n=57)$ physicians are against providing advice regarding the screening and prevention of elderly falls only if the patient requests it. Table 4showsthe reported attitudes of primary health care physicians toward elderly fall screening and prevention. 
Table 4 -The attitudes of primary health care physicians toward elderly fall screening and prevention

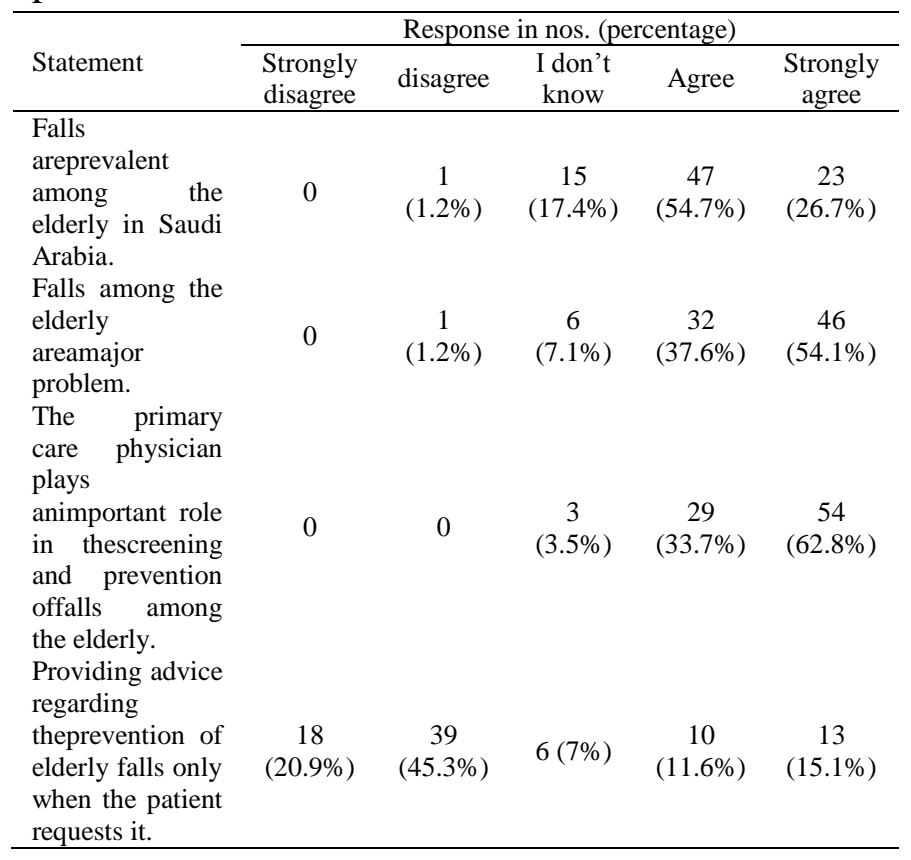

Practices assessment: Among primary health care physicians, $35.5 \%$ did not follow any guidelines in dealing with elderly patients regarding the screening and prevention of falls. Only $15.1 \%$ of physicians always ask their elderly patients about any history of falls, andin contrast $16.3 \%$ never ask, while $66.2 \%$ of the doctors had examined an elderly patient for fall risk assessment at least once.

Furthermore, $26.7 \%$ of the physicians always advisetheir elderly patients to exercise, and only $4.7 \%$ never so advise them. Moreover, $19.8 \%$ of the physicians always prescribe vitamin D as part of elderly fall prevention fortheir patients, while $3.5 \%$ never prescribe it.

Of the 86 doctors, 46 (53.5\%) had never received training onelderly fall screening and prevention. Please refer to Table 5.
Table 5 -The practice of primary health care physicians toward elderly fall screening and prevention

\begin{tabular}{|c|c|c|c|c|}
\hline \multirow{2}{*}{ Statement } & \multicolumn{4}{|c|}{ Response in nos./percentage } \\
\hline & Never & Sometimes & Often & Always \\
\hline If following & & & & \\
\hline $\begin{array}{lr}\text { guideline } & \text { for } \\
\text { screening } & \text { and } \\
\text { prevention } & \text { of } \\
\text { elderly falls. } & \end{array}$ & $\begin{array}{c}30 \\
(35.5 \%)\end{array}$ & $\begin{array}{c}31 \\
(36.5 \%)\end{array}$ & $\begin{array}{c}14 \\
(16.5 \%)\end{array}$ & $\begin{array}{c}10 \\
(11.8 \%)\end{array}$ \\
\hline $\begin{array}{l}\text { If routinely asking } \\
\text { elderly patients for } \\
\text { history of falls. }\end{array}$ & $\begin{array}{c}14 \\
(16.3 \%)\end{array}$ & $\begin{array}{c}29 \\
(33.7 \%)\end{array}$ & $\begin{array}{c}30 \\
(34.9 \%)\end{array}$ & $\begin{array}{c}13 \\
(15.1 \%)\end{array}$ \\
\hline $\begin{array}{l}\text { If examining an } \\
\text { elderly person for } \\
\text { fall } \\
\text { assessment. }\end{array}$ & $\begin{array}{c}29 \\
(33.7 \%)\end{array}$ & $\begin{array}{c}26 \\
(30.2 \%)\end{array}$ & $\begin{array}{c}24 \\
(27.9 \%)\end{array}$ & $\begin{array}{c}7 \\
(8.1 \%)\end{array}$ \\
\hline $\begin{array}{l}\text { If ever trained } \\
\text { about screening } \\
\text { and prevention of } \\
\text { elderly falls. }\end{array}$ & $\begin{array}{l}46 \\
(53.5 \%)\end{array}$ & $\begin{array}{l}19 \\
(22.1 \%)\end{array}$ & $\begin{array}{l}13 \\
(15.1 \%)\end{array}$ & $\begin{array}{l}8 \\
(9.3 \%)\end{array}$ \\
\hline $\begin{array}{l}\text { If advising elderly } \\
\text { patient to exercise. }\end{array}$ & $\begin{array}{l}4 \\
(4.7 \%)\end{array}$ & $\begin{array}{l}21 \\
(24.4 \%)\end{array}$ & $\begin{array}{l}38 \\
(44.3 \%)\end{array}$ & $\begin{array}{l}23 \\
(26.7 \%)\end{array}$ \\
\hline $\begin{array}{l}\text { If prescribing } \\
\text { vitamin } D \text { for } \\
\text { elderly patients. }\end{array}$ & $\begin{array}{l}3 \\
(3.5 \%)\end{array}$ & $\begin{array}{l}25 \\
(29.1 \%)\end{array}$ & $\begin{array}{l}41 \\
(47.7 \%)\end{array}$ & $\begin{array}{l}17 \\
(19.8 \%)\end{array}$ \\
\hline
\end{tabular}

Regarding the MORSE Falls Risk Assessment for the elderly, $49 \%$ of our primary health care physicians were not familiar with it and 66\% had never beentrained in it, as shown in Figure 1.

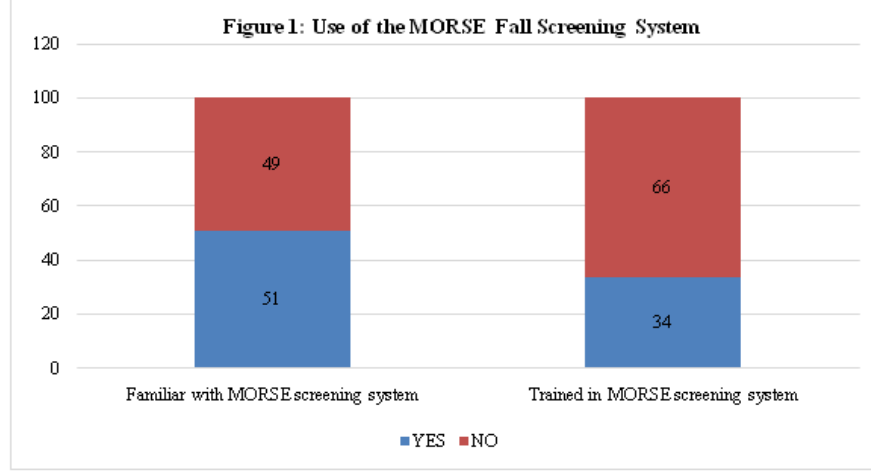

\section{Discussion}

From the knowledge evaluation we can see that the knowledge of primary health care physicians at the ALWAZARAT Health Center was divided thus: good, 27.9\%; intermediate, 39.5\%; low, $31.4 \%$, and $1.2 \%$, very low. The reasons for the low level of knowledge of the physicians might be due to the facts that:

1) $35.5 \%$ of physicians never follow any guidelines about the screening and prevention of elderly falls. 
2) $53.5 \%$ of physicians have never been trained in the screening and prevention of elderly falls.

3) There is alack of Saudi recommendations or guidelines about elderly fall screening and prevention.

Although there is a lack of studies of falls among the elderly in Saudi Arabia and their risks of complications, most of the doctors agreed orstrongly agreed that falls among the elderly area prevalent and major problem due to their background knowledge about the complications of falls, mainly among the elderly female population. In this study, around $54.7 \%$ of physicians strongly agreed with the need to ask their elderly patients about their history of falls in the last year as part of screening, while in practice only $15.1 \%$ of them reported asking for their history of falls, which is not good in light of the simplicity of this question, which is so significant in the screening of the elderly. On the other hand, around $60 \%$ of the physicians did not take into consideration thatone fall doubles the risk among the elderly of another fall, which perhaps is whythey answered that they donot ask for the history of previous falls.

In thisstudy, only $27.9 \%$ of physicians strongly agreed with theuse of vitamin D to prevent elderly falls, but only $19.8 \%$ always prescribe it as part of prevention. This discrepancy might be due to the low level of knowledge thatvitamin D is the best intervention for the prevention of falls or the recommended dose.

In the practice assessment, only $26.7 \%$ always advise their elderly patientstoexercise, and we should determine the barriers resulting in thatlow rate.

Our results also show that around half of the physicians consider 60 years of age as elderly, which resembles the $\mathrm{WHO}$ definition that the elderly aredefined by the occupational retirement age.

Finally, resident physicians represented the majority of the study sample, which is due to the fact that the ALWAZARAT Center is the largest center for family medicine program training in Saudi Arabia, providing full services in medical consultation and patient management. Around $71 \%$ of the physicians interviewed have only a bachelor's degree.

\section{Limitations of the study}

The results of this study might show bias as a result ofparticipantschoosing what they think to be the favored answer rather than answering honestly.

Moreover, this study covered only primary health care physicians in the ALWAZARAT Center, who might well not be representative of primary health care physicians atother centers. Also, a predominance of post-graduates might have affected the study results.

\section{Conclusion}

Primary health care physicians at the ALWAZARAT Primary Health Care Center in Saudi Arabia vary in their level of elderly fall screening and prevention, with to the largest group at the intermediate level ( $n=34,39.5 \%)$. However, further studies are required to assess the knowledge, attitudes, and practices ofprimary health care physicians at other centers. We should search for barriers that can affect aproper system of screening and prevention of elderly falls, as well as institute more educational programs and establish agreed local recommendations for the screening and prevention of elderly falls and an approved screening scale.

\section{Acknowledgement}

I would like to thank all the PHC physicians who participated in this study and extend my special thanks to the Program Director of family physiciansat the ALWAZARATCenter, DR. SAAD ALBATTAL. Also, I would like to extend thanks to DR.TAREK ELSAIED, the supervisor of this research, and Prof. MOSTAFA KOFI, Head of the Research Unit.

\section{References}

1. Proposed working definition of an older person in Africa for the MDS Project 
[Internet]. World Health Organization. World Health Organization; [cited 2017Aug1]. Available from: http://www.who.int/healthinfo/survey/agei ngdefnolder/en/4. World Health Organization: Towards policy for health $\&$ aging, 2011.

2. Definition of "fall": Cambridge English Dictionary [Internet]. Dictionary. cambridge.org. 2017 [cited 18 October 2017]. Available from: http://dictionary.cambridge.org/dictionary/ english/fall.

3. Important Facts about Falls [Internet]. Centers for Disease Control and Prevention. Centers for Disease Control and Prevention; 2017 [cited 2017Aug1]. Available from: http://www.cdc.gov/homeandrecreationals afety/falls/adultfalls.html.

4. A Global Report on Falls Prevention Epidemiology of Falls [Internet]. [cited 19 October 2017]. Available from: http://www.who.int/ageing/projects/1.Epid emiology $\% 20$ of $\% 20$ falls $\% 20$ in $\% 20$ older $\% 20$ age.pdf.

5. Al Senany S, Al Saif A. Assessment of physical health status and quality of life among Saudi older adults. Journal of physical therapy science 2015;27(6):16911695.

6. Alexander BH, Rivara FP, Wolf ME. The cost and frequency of hospitalization for fall-related injuries in older adults. American Journal of Public Health 1992;82(7):1020-1023.

7. Sterling DA, O'Connor JA, Bonadies J. Geriatric falls: injury severity is high and disproportionate to mechanism. Journal of Trauma-Injury, Infection and Critical Care 2001;50(1):116-119.

8. Incidence of and Risk Factors for Falls and Injurious Falls among the Communitydwelling Elderly [Internet]. researchgate. [cited 19 October 2017]. Available from:
https://www.researchgate.net/profile/Samy _Suissa/publication/31332859_Incidence_ of_and_Risk_Factors_for_Falls_and_Injur ious_Falls_among_the_Communitydwelling_Elderly/links/0deec51ee7ca6a71 b2000000/Incidence-of-and-Risk-Factorsfor-Falls-and-Injurious-Falls-among-theCommunity-dwelling-Elderly.pdf.

9. Owens PL, Russo CA, Spector W, Mutter R. Emergency department visits for injurious falls among the elderly, 2006: Statistical Brief\#80.

10. Falls in older people: assessing risk and prevention | Guidance and guidelines | NICE [Internet]. Nice.org.uk. 2013 [cited 19 October 2017]. Available from: https://www.nice.org.uk/guidance/cg161/c hapter/1-recommendations.

11. Summary of the Updated American Geriatrics Society/British Geriatrics Society Clinical Practice Guideline for Prevention of Falls in Older Persons [Internet]. americangeriatrics.org. [cited 19 October 2017]. Available from: https://www.americangeriatrics.org/files/d ocuments/health_care_pros/JAGS.Falls.Gu idelines.pdf.

12. Falls in older persons: Risk factors and patient evaluation [Internet]. [cited 2016 Mar 5]. Available from: http://www.uptodate.com/contents/falls-inolder-persons-risk-factors-and-patientevaluation.

13. Lanier J, Mote M, Clay E. Evaluation and Management of Orthostatic Hypotension [Internet]. Aafp.org. 2011 [cited 19 October 2017]. Available from: http://www.aafp.org/afp/2011/0901/p527.h tml.

14. Pirozzo S, Papinczak T, Glasziou P. Whispered voice test for screening for hearing impairment in adults and children: systematic review. BMJ 2003; 327:967.

15. Moyer VA, U.S. Preventive Services Task Force. Prevention of falls in community- 
dwelling older adults: U.S. Preventive

Services Task Force recommendation statement. Ann Intern Med 2012; 157:197.

16. Cameron ID, Murray GR, Gillespie LD, Robertson MC, Hill KD, Cumming RG, et al. Interventions for preventing falls in older people in nursing care facilities and hospitals. Cochrane Database Syst Rev 2010;(1):CD005465.

17. [Internet]. surveysystem.com. [cited 19 October 2017]. Available from: https://www.surveysystem.com/samplesize-formula.htm.

18. Research Randomizer [Internet]. Randomizer.org. [cited 19 October 2017]. Available from: https://www.randomizer.org.

\section{QUESTIONNAIRE}

Iam SAAD ALSHAHRANI, a family physician in the residency training program. This questionnaire is part of a study assessing the knowledge, attitudes, and practices of primary health care physicians regardingthe screening of falls in the elderly. The aim of this study is to improvethe implementation of elderly patient care.

By participating in this questionnaire, you agree to take part in this study, and all the information provided by you is strictly confidential. You or your practice will not be identified in any reports or publications that may result from this study.

For any questions you can contact me at:

email: saadshebnan@gmail.com

Mobile: 966567999456

My supervisor is DR.TAREK ELSAIED.

The contact number of DR.TAREK: 2910807/33933

Thank you for your cooperation.

\section{Please answer the followingquestions:}

1. AGE:
2. GENDER:
( ) male
( ) female

3. JOB TITLE:( ) resident ( ) registrar ( ) senior registrar ( ) consultant

4. QUALIFICATION: ( ) MBBS ( ) MRCGP ( ) Saudi Board of FM ( ) Arab Board of FM other:

5. YEARS OF PRACTICE SINCE GRADUATION:

6. BASED ON THE WHO DEFINITION OF THE ELDERLY, THE ELDERLY IN SAUDI ARABIA ARE
PERSONS AGED: ( ) > 50y
( ) $>60 \mathrm{y}$
( ) $>70 \mathrm{y}$
( ) I don't know 
THE NEXT QUESTIONS WILL EVALUATE THE KNOWLEDGE OF PRIMARY HEALTH CARE PHYSICIANS

\begin{tabular}{|c|c|c|c|c|c|}
\hline \multirow[b]{2}{*}{ Question } & \multicolumn{5}{|l|}{ Answer } \\
\hline & $\begin{array}{l}\text { Strongly } \\
\text { disagree }\end{array}$ & disagree & $\begin{array}{l}\text { I don't } \\
\text { know }\end{array}$ & Agree & $\begin{array}{l}\text { Strongly } \\
\text { agree }\end{array}$ \\
\hline $\begin{array}{l}\text { 7. To screen the risk of fall among elderly } \\
\text { persons, we have to ask all elderly if they } \\
\text { have fallen in the last } 12 \text { months. }\end{array}$ & & & & & \\
\hline $\begin{array}{l}\text { 8. Multifactorial risk assessment is used for the } \\
\text { elderly with recurrent falls or gait and } \\
\text { balance abnormality. }\end{array}$ & & & & & \\
\hline $\begin{array}{l}\text { 9. DM, HTN, and other comorbidities will } \\
\text { increase the risk of falls among elderly } \\
\text { patients. }\end{array}$ & & & & & \\
\hline $\begin{array}{l}\text { 10.Visual, hearing, gait, and cognitive } \\
\text { assessments should be usedas a part of the } \\
\text { multifactorial risk assessment of falls in the } \\
\text { elderly. }\end{array}$ & & & & & \\
\hline $\begin{array}{l}\text { 11. Orthostatic hypotension is one of the } \\
\text { important risk factors for falls, and is defined } \\
\text { as a decrease in systolic blood pressure of } 20 \\
\text { mmHg or decrease in diastolic blood pressure } \\
\text { of } 10 \mathrm{mmHg} \text { within } 3 \text { minutes of standing in } \\
\text { comparison to the sitting or supine position. }\end{array}$ & & & & & \\
\hline $\begin{array}{l}\text { 12.Falling once doubles the chance among the } \\
\text { elderlyof falling again. }\end{array}$ & & & & & \\
\hline $\begin{array}{l}\text { 13.Hemoglobin, urea, creatinine, glucose, and } \\
\text { vitamin D can help detect the risk of falls in } \\
\text { elderly patients. }\end{array}$ & & & & & \\
\hline $\begin{array}{l}\text { 14. We have to review elderly medications as a } \\
\text { part of fall risk assessment. }\end{array}$ & & & & & \\
\hline $\begin{array}{l}\text { 15. The recommended interventions for } \\
\text { prevention of falls among elderly are: An } \\
\text { exercise program, managing risk } \\
\text { factors,dealing with environmental factors, } \\
\text { and vitamin D supplement. }\end{array}$ & & & & & \\
\hline $\begin{array}{l}\text { 16. The best intervention to decrease the rate of } \\
\text { falls in the long term is vitamin D } \\
\text { supplements. }\end{array}$ & & & & & \\
\hline $\begin{array}{l}\text { 17. The recommended dose of vitamin } \mathrm{D} \\
\text { supplements for the prevention of falls in the } \\
\text { elderly }>70 \text { is } 800 \mathrm{IU} / \text { day. }\end{array}$ & & & & & \\
\hline $\begin{array}{l}\text { 18. The recommended dose of vitamin } \mathrm{D} \\
\text { supplement for the prevention of falls in }\end{array}$ & & & & & \\
\hline
\end{tabular}


those aged 50-70 is $600 \mathrm{IU} /$ day.

THE NEXT QUESTIONS WILL EVALUATE THE ATTITUDES OF PRIMARY HEALTH CARE PHYSICIANS

\begin{tabular}{|l|l|l|l|l|l|}
\hline \multirow{2}{*}{ Question } & $\begin{array}{l}\text { Strongly } \\
\text { disagree }\end{array}$ & Disagree & $\begin{array}{l}\text { I don't } \\
\text { know }\end{array}$ & Agree & $\begin{array}{l}\text { Strongly } \\
\text { agree }\end{array}$ \\
\hline $\begin{array}{l}\text { 19. Do you think that falls among the elderly in } \\
\text { Saudi Arabia are prevalent? }\end{array}$ & & & \\
\hline $\begin{array}{l}\text { 20. Do you agree that falls among the elderly are a } \\
\text { major problem? }\end{array}$ & & & & \\
\hline $\begin{array}{l}\text { 21. PHC physiciansplay animportant role in the } \\
\text { screening and preventionof falls among elderly } \\
\text { patients. }\end{array}$ & & & & \\
\hline $\begin{array}{l}\text { 22. I would only provide advice regarding the } \\
\text { prevention of falls among the elderly when the } \\
\text { patient requests it. }\end{array}$ & & & & \\
\hline
\end{tabular}

THE NEXT QUESTIONS WILL EVALUATE THE PRACTICES OF THE PRIMARY HEALTH CARE PHYSICIAN

Question

23. Are you following any guidelines in thescreening and prevention of falls among the elderly?

24.Doyou routinely ask your elderly patients about their history of falls?

25. Have you ever examined an elderly person for falls risk assessment?

26. Were you ever trained in thescreening and prevention of falls among the elderly?

27. Do you advise your elderly patients to exercise?

28. Do you prescribe your elderly patient vitamin D supplements?

MORSE Fall Screening System

Question

Answer

\begin{tabular}{|l|l|l|l|}
\hline Always & Often & Sometimes & never \\
\hline
\end{tabular}

29. In our center we use theMORSE Fall Risk Assessment for the elderly.Are you familiar with it?

30.Were you ever trained inour MORSE Fall Risk Assessment? 